\title{
Strategic Planning of Education in Total Quality Management State Vocational
}

\author{
Siti Munirotul Yuanita \\ Department of Educational Administration \\ Universitas Negeri Malang, Indonesia \\ munirotulyuanita@gmail.com
}

\author{
Anjar Agus Firawati \\ Department of Educational Administration \\ Universitas Negeri Malang, Indonesia \\ anjarfira@gmail.com
}

\author{
Anggraeni Cahyaningtyas \\ Department of Educational Administration \\ Universitas Negeri Malang, Indonesia \\ anggraenityas18@gmail.com
}

\author{
Asfi Mangzila \\ Department of Educational Administration \\ Universitas Negeri Malang, Indonesia \\ asfimangzila12@gmail.com
}

\author{
Quma Irah Larasati \\ Department of Educational Administration \\ Universitas Negeri Malang, Indonesia \\ qumairla7@gmail.com
}

\begin{abstract}
Research on educational strategic planning carried out at Vocational High School 4 Malang (SMKN 4 Malang) aims to find out how the education strategic planning, formulation of the school's vision and mission for Total Quality Management (TQM), who are the parties involved, what the tools are used for educational strategic planning, and what things are seen to find out the increase in the quality of education. The method used is through interviews and observations. The results of this study are the strategic planning carried out at SMK 4 Malang shown by the existence of Rencana Kegiatan dan Anggaran Sekolah (RKAS), Rencana Kegiatan Sekolah (RKS), and Rencana Strategies (Renstra); school vision and mission formulated by all parties and published to the public; all parties involved in the planning process from the school managerial to external parties such as school committees and the community; the stages of planning are done through system analysis, policy formulation and action planning, tools used in problem solving using Strength, Weakness, Opportunity, Threat (SWOT) analysis and brainstorming all elements of the principal, teachers, employees, committees, and parents of students, and the success of the quality of school education can be seen from the addition students who register from Penerimaan Peserta Didik Baru (PPDB).
\end{abstract}

Keywords: strategic planning, total quality management

\section{INTRODUCTION}

Total Quality Management (TQM) is an approach in running a business that tries to maximize the competitiveness of an organization through continuous improvement of its products, services, people, processes, and environment [1]. In TQM, the processes are not much different from other managements, those are, it starts with planning and ends with an evaluation. But in TQM, after evaluating it will be implemented continuously. Planning is a rational and systematic thought process of what will be done, how to do it, when it is done, and who will do an activity that is done to improve the quality so that the activities can be effective, efficient, and productive and meet the demands and needs of the community [2].

The planning that occurs in TQM is called strategic quality planning, or which can be interpreted as the process of preparing steps for a comprehensive activity in a systematic, rational, intricate, and long-term manner and based on certain visions, missions and principles to meet basic and overall needs for customers. The need for these strategic efforts to develop institutional plans [3]. Strategic planning allows the formulation of long-term priorities and institutional changes based on rational considerations. Without the strategies, an institution cannot be sure how they can take the advantages of new opportunities [4].

The need for strategic efforts to develop agency plans. The real significance is that it distracts senior managers from daily issues and emphasizes a reexamination of the institution's main objectives about its customers. In the education sector, [5] Revealed there are Three Stages of Planning Strategies in education management operations. The stages of planning work consist of system analysis, policy formulation and action planning.

Strategic planning must be addressed following the vision, mission, and goals of the institution. A mature education plan will be able to facilitate the institution in achieving strategic objectives, administrative objectives, and development objectives. Thus, the aspect of the quality of education is always a concern as planned and reflected by the institution's vision [6]. The statement of the ultimate goal outlines vision from an institution and for what that vision is achieved [4].

The vision must be brief, direct and shows the ultimate goals of the institution, for example: All our students will succeed. The mission statement is closely related to the vision and provides clear direction both for the present and for the future. The mission statement makes the vision clear why an institution is different from other institutions. It should be emphasized that the mission must be translated into important steps needed in exploiting the opportunities that exist [4].

Educational institutions often feel reluctant to convey to the general public that they are trying to be the best in their work environment. There is a concern that if the mission statement is disclosed, their chances of failure will increase. However, if the mission statement is supported by a long-form quality strategy that is well formulated, then that goal must be disclosed in the 
mission statement. Good market research is an important element in the implementation of TQM.

This research is the main way to listen to customers and potential customers. If the TQM approach is reconsidered, then the quality according to what the customer feels must be immediately determined. Market research can be used to determine quality issues through the customers' perspective [4]. The research will provide data that will complement the institutions' impression of various groups of customers or prospective customers. Institutions must know what various groups are thinking. Different customer groups have different needs so that different approaches and forms of treatment are needed. Institutions will only know the difference in the market when the institutions have evidence about it.

The market analysis must be included as an important element in market segmentation. Different markets need to be identified, if market identification is successful, questions need to be raised regarding the various needs of each segment and whether a service needs will be adjusted to specific needs. This is very important, especially for larger institutions of higher education where students have different perceptions and needs from previous graduates [4].

SWOT is an abbreviation of Strengths, Weaknesses, Opportunities, and Threats. SWOT analysis has become a common tool used in educational strategic planning but remains an effective tool in locating the potential of institutions [4]. The performance of an organization becomes very vital in the development of an educational institution. Organizational strategies include short-term and long-term objectives formulated to be one of the factors that affect organizational performance [7].

In education, the situation analysis should be followed up with the use of SWOT analysis techniques, covering the activity of evaluation of the strengths and weaknesses of the internal education system as well as opportunities and threats originating from outside the education system. Situational audits are based on existing values, support, and capabilities [8].

Thus, will be able to know the strengths and weaknesses and needs that can support the achievement of the implementation of education. The October 2002, Education Sector Review (ESR), provides an account of recent education sector performance. Some of the main findings of the ESR have been incorporated in Table 1.2 an Education Sector "SWOT Analysis", in which strengths are matched against opportunities and weaknesses interpreted in terms of possible threats [9].

SWOT analysis is a form of situation and condition analysis that is descriptive in nature which involves setting specific goals of business or project speculation and identifying internal and external factors that support and which do not achieve these goals [3] Also in using SWOT analysis, it can use brainstorming by all elements, from top elements such as school principals to teachers and employees.

It is explained [10] for the successful implementation of TQM in education quality circles are to be formed. A quality circle consists of small groups of people that meet regularly to discuss problems to seek solutions and to cooperate with management in the implementation of those solutions. Quality circles utilize organized approaches to problem-solving, operate on the principle that employee participation in decision making and problem-solving improves the quality of work. In education quality deals with monitoring and identifying the areas that affect the levels of teachings". With brainstorming carried out by all elements, it can be used to solve problems that occur so that the quality and quality of the institution increases.

If a school wants to continue to advance the quality or quality of its education, the school must implement TQM because it is focused on customer or community satisfaction. Thus, the school can continue sold well in the eyes of the community and people flock to want to go to school there or send their children to school there. To make the school desired by the community first, the school must plan what strategic things are needed so that the quality of the school is better in the eyes of the community.

Planning is very important to achieve the goals of an institution thus it can be achieved effectively and efficiently. SMK 4 Malang is a very popular vocational school and loved by the community. People always flock to want to go to school there. Public's perception of SMKN 4 Malang is a very good school according to the quality of education.

Thus, people are not reluctant to study there. Even the public is competing to fight to become students in SMK 4 Malang. Seeing the success of schools by the enthusiasms of people who want to go to SMKN 4 Malang and the well-known of SMKN 4 Malang as good quality schools, the researcher wants to examine how the strategic planning carried out by SMKN 4 Malang in Total Quality Management of their education.

\section{METHOD}

This research used descriptive qualitative research methods, while the type of qualitative research is case studies because what skill examined was strategic planning in the school. Through this research, the researcher wanted to obtain a complete and in-depth description of an entity, which referred to intact here that is in the case study of the investigation not only about the results but also related to the investigation of an entity's process and depth, the intention is that research is also related to intrinsic aspects in the case under study.

Case studies are carried out on a unified system, where the system can be in the forms of activities, programs, events, or groups that are bound by time, place, or other ties. The techniques used by researchers were interviews, observation and documentation. The technique used to obtain relevant, accurate and in-depth data. This research was conducted at SMK 4 Malang located on Jalan Tanimbar 22 Malang City.

Following the implementation steps are divided into several stages, namely: (1) Preliminary or licensing stage to the Principal of SMKN 4 Malang; (2) Implementation Phase, namely conducting interviews with school principals and related instruments, conducting observations in the school environment, and documenting all data relating to the focus of the study; (3) The reporting stage is to write down the research results obtained in the form of a report or article. 


\section{RESULTS}

The results obtained from this study are as follows: School strategic planning is based on 8 national education standards, all of which refer to these 8 standards. For example, the standard process, how the Kegiatan Belajar Mengajar (KBM) implemented at school, it means planning the learning, planning the devices to be made, planning about when the learning will begin and planning the learning for several minutes. All of the examples refer to 8 education standards.

For example, the evaluation standard again, means that it refers to how the evaluation was made, we planned it, because if it was not planned it would not be possible to conduct a test, the evaluation would be like what the model would like Computer Based Test (CBT) or Paper Based Test (PBT). This means that everything planned is made into a program, after that, how is the budget planned. Therefore, the activity plan, after our activity plan is made for a program, after making a new program plan it was outlined in the work plan or activity and its budget.

All of those were manifested in RKS, RKAS, and Rienstra. RKAS must be discussed with all managements after all managements had agreed, then it can be discussed with the school committee along with all parents of students invited every year. That was the process of determining activities in school. To formulate a vision and mission, it must be based on management group discussion or can be called brainstorming.

After the visions were translated into missions, the mission must also be revised following the changes that occurred, the mission must be measurable, for example, the vision of environmental elements, the management must enter the environmental elements because it kept up to the Adhiwityata program. All of these visions and missions were based on input and discussion from management groups as well as other parties as well as school committees and will be published publicly through the school banner and school website.

The tools used in problem-solving use a SWOT analysis, first review, for example, what were the strengths and weaknesses of the school, what challenges, what opportunities do we present. For example, schools had completed advantages of facilities, but the weakness of inadequate facilities or the internet was slow. Hence, the school analyzed weaknesses first, then fixed them and rose up the opportunities. In other words, the school also conducted brainstorming for all of the parties involved in school management.

The parties responsible for school strategic planning are all the elements involved in the planning, namely the principal, all school managerial managers, such as vice principle, counselling guidance, library, head of the program and parties outside the school such as committees, parents of students, etc.

The stages in the planning process begin with a meeting of all relevant stakeholders, to saw the deficiencies or errors in last year activities or programs, plan a new program, conducted a SWOT analysis and brainstorm problems and established policies regarding which programs should be maintained, improved, revised and abolished, stipulating approved programs and activities, written in RKS, RKAS, and Strategic Plan, announced to all parties openly. To find out the quality of schools increasing or decreasing schools have never conducted market research, the schools look at the indicators directly from PPDB to find out market interest. It means that even though we have not conducted market research yet, the involved parties knowing their interest from the PPDB indicator.

\section{DISCUSSION}

SMKN 4 Malang has planned education quality strategic by making vision and mission, RKS, RKAS, and Strategic Plan to meet 8 National Education Standards which are discussed with all management after all management has agreed then can be discussed with the school committee along with all parents of students invited every year. This in accordance with the opinion [3] which state that strategic quality planning is the process of compiling steps in a comprehensive activity in a systematic, rational, intricate, and long-term manner and based on certain visions, missions and principles to meet basic and overall needs for customers.

In formulating the vision and mission of SMK 4 Malang it is adapted to the changing times and the existing environment, it also involves all of stakeholders involved in the discussion. The ready-made vision and mission will be immediately published by the school to the community so that the community knows and able to assess the quality of the school. That is what refutes the opinion of [4] who wants educational institutions often feel reluctant to convey to the general public that they are trying to be the best in their work environment. There is a concern that if the mission statement is disclosed, their chances of failure will increase.

The tool used in problem-solving uses SWOT analysis and brainstorming. This is consistent with the opinion of [4] which states that SWOT analysis has become a common tool used in educational strategic planning, but it remains an effective tool in placing the potential of institutions. In line with the opinion of [10] which states quality circles utilize organized approaches to problem-solving, operate on the principle that employee participation in decision making and problemsolving improves the quality of work.

The parties responsible for school strategic planning are all of the elements involved in the planning, namely the principal, all those responsible for school management, such as vice principle, Counseling Guidance, libraries, program leaders and parties outside the school such as committees, parents of students, etc. other. This is following the opinion of [10] that for the successful implementation of TQM in education quality circles are to be formed. A quality circle consists of small groups of people that meet regularly to discuss problems to seek solutions and to cooperate with management in the implementation of those solutions.

The stages in the planning process begin with a meeting of all relevant stakeholders, see deficiencies or errors in last year activities or programs (system analysis), plan a new program, conduct a SWOT analysis and brainstorm problems and to establish policies regarding which programs should be maintained, amended, revised and abolished (policy formulation), stipulates approved programs and activities, written in RKS, RKAS, and 
Renstra (action planning), announced to all parties openly. This is following the opinion of [5] revealed that there are three Stages of Planning Strategies in education management operations. The stages of planning work consist of system analysis, policy formulation and action planning.

To find out the quality of schools increasing or decreasing schools have never conducted market research. Yet, schools look at the indicators directly from PPDB to find out market interest. It means that even though the parties involved have not conducted market research, they know their interest from the PPDB indicator. It is the reverse of Salis' opinion (2010) which states that good market research is an important element in the implementation of TQM. The parties involved in SMK 4 Malang does not need market research because they can assess the success of their quality.

\section{CONCLUSION}

Based on the explanation above, it can be concluded that: (1) strategic planning carried out at SMK 4 Malang is shown by the existence of RKAS, RKS, and strategic planning; (2) the formulation of the vision and mission of SMK 4 Malang is adjusted to the changing times and the existing environment, also involving all stakeholders involved in the discussion. The ready-made vision and mission will be immediately published by the school to the community so that the community knows and can assess the quality of the school; (3) all parties involved in the planning process both from the school managerial to outside parties such as the committee and students' parents; (4) the tool used in problem solving uses SWOT analysis and brainstorming all elements of the principal, teachers, employees, committees, and parents of students; (5) the stages in the planning process begin with a meeting of all relevant stakeholders, see deficiencies or errors in last year activities or programs, plan a new program, conduct a SWOT analysis and brainstorm problems and to establish policies regarding which programs should be maintained, improved, revised, and abolished, stipulating approved programs and activities, written in RKS, RKAS, and strategic planning, announced to all parties openly; and (6) the improvement in school quality seen from the market interest based on increasing of the number of students who register from PPDB.

\section{REFERENCES}

[1] Juharni. 2017. Manajemen Mutu Terpadu (Total Quality Management). Makassar: CV Sah Media

[2] Machali, I., and Hidayat, A. 2016. The Hand Book of Education Management: Teori dan Praktik Pengelolaan Sekolah / Madrasah di Indonesia. Jakarta: Kencana.

[3] Djafri, N., and Rahmat, A. 2017. Buku Ajar Manajemen Mutu Terpadu. Yogyakarta: Zahir Publishing.

[4] Sallis, E. 2010. Manajemen Mutu Terpadu Pendidikan. Jogjakarta: IRCiSoD.

[5] Chang, G. C. 2008. Strategic Planning in Education: Some Concepts and Methods. Paris: International Institute for Educational Planning.

[6] Mubarok, M. S. 2019. Implementasi Perencanaan Strategis dalam Pengembangan Program Studi Manajemen Pendidikan Islam S1 Universitas Islam Negeri Sunan Kalijaga. Tesis. Retrieved June 13, 2019, from http://digilib.uin-suka.ac.id/34406/1/1620410016_BABI_IV-atau-V_DAFTAR-PUSTAKA.pdf.

[7] Noe, at all. 2006. Human Resources Management Gaining a Competitive Advantage. New York: McGraw Hill International Edition.

[8] Khori, A. 2016. Manajemen Strategik dan Mutu Pendidikan Islam dalam Manajerial. Jurnal Pendidikan Islam. Retrieved June 10, 2019, from https://www.google.com/url?sa=t\&source=web\&rct=j\&ur.

[9] Goverment of Gana. 2003. Education Strategic Plan 2003 to 2015. Gana: Ministry of Education.

[10] Wani I. A., and Mehraj H. K. 2014. Total Quality Management in Education: An Analysis. International Journal of Humanities and Social Science Invention. Retrieved June 10, 2019, from http://www.ijhssi.org/papers/v3(6)/Version-

4/N0364071078.pdf\&ved=2ahUKEwiN5eX_xO3jAhVFv Y8KHW01AdUQFjANegQIBRAB\&usg=AOvVaw2nK98 sg_3DXB4oma5VSJ8g. 